Задольський А.М. канд. економ. наук, доиент ORCID ID: 0000-0002-0580-2243

Національний технічний університет Украӥни «Київський політехнічний інститут імені Ігоря Сікорського»

\title{
ЕКОНОМІЧНА СУТНІСТЬ ТА МЕТОДИЧНІ ПІДХОДИ ДОЦІЛЬНОСТІ МОДЕРНІЗАЦІЇ ПРОМИСЛОВОГО УСТАТКУВАННЯ
}

\section{ЭКОНОМИЧЕСКАЯ СУЩНОСТЬ И МЕТОДИЧЕСКИЕ ПОДХОДЫ ЦЕЛЕСООБРАЗНОСТИ МОДЕРНИЗАЦИИ ПРОМЫШЛЕННОГО ОБОРУДОВАНИЯ}

\section{ECONOMIC ESSENCE AND METHODICAL APPROACHES OF ADVISABILITY OF INDUSTRIAL EQUIPMENT MODERNIZATION}

Статтю присвячено проблемам оновлення виробничого апарату підприємств виробничої сфрери (незалежно від видів діяльності та форм власності) як найбільш активного елементу виробництва. Доведено, щяо виробничий апарат підприємств $i$, в першу чергу, наявне на підприємстві устаткування, можна оновити $і$ довести до сучасного рівня в існуючих господарських умовах, в першу чергу за рахунок модернізації. Тобто модернізацію діючого устаткування на промислових підприємствах необхідно розглядати в якості більш альтернативного варіанту оновлення порівняно з придбанням нового аналогічного устаткування. У статті також дістало подальшого розвитку поняття «модернізачія устаткування», яке, на відміну від хибно існуючих визначень, не $\epsilon$ будь-яким удосконаленням існуючих застарілих зразків, а таким удосконаленням устаткування з метою досягнення ним показників та характеристик найсучасніших у світі аналогічних зразків. Практичне значення проведеного у статті дослідження полягає у розробиі зручної для практичного використання універсальної методики щьодо прийняття рішення про економічну доцільність здійснення модернізації устаткування як промислового, так $і$ побутового призначення.

Ключові слова: модернізація, промислове устаткування, методичні підходи, удосконалення, доцільність модернізації промислового устаткування.

Статья посвящена проблемам обновления производственного аппарата предприятий производственной сферы (независимо от видов деятельности и форм собственности), как наиболее активного элемента производства. Доказано, что производственный аппарат предприятий $u$, в первую очередь, имеющееся на предприятии оборудование, можно обновить и довести до современного состояния в существующих хозяйственных условиях за счет модернизации. Другими словами, модернизаџию оборудования на промылиленных предприятиях необходимо рассматривать в качестве альтернативного варианта по сравнению с приобретением нового аналогичного оборудования. В данной статье получило дальнейшее развитие само определение понятия «модернизачия оборудования», которое в противоположность ошибочно существующих определений не является всяким улучшением существующих устаревших образиов оборудования. С нашей точки зрения понятие «модернизация оборудования» представляет такие усовершенствования, которые способствуют достижению оборудованием показателей и характеристик современньх мировых аналогичных образиов. Практическое значение выполненного исследования в рамках 
данной статьи состоит в разработке удобной для практического использования универсальной методики принятия решений относительно экономической цеелесообразности выполнения модернизации оборудования как промышленного, так и бытового назначения.

Ключевые слова: модернизация, производственный аппарат предприятий, промышленное оборудование, методические подходы, усовершенствование оборудования, целесообразность модернизации оборудования.

The article is devoted to problems of upgrade of enterprises production facilities in the production sector (irrespective of kinds of business and ownership) as the most active element of production. It is proven that the production device of companies can update and bring up to date in the current economic conditions and primarily available at the company facilities, primarily due to modernization. That is to say modernization of existing equipment in industrial plants should be considered as a renewal alternative compared to purchasing new similar equipment. It also acquired a further development of the concept of modernization of the equipment which is improving to reach this equipment parameters and features the latest in the world of similar designs, but in any case this term is not any improvement of existing outdated designs. The practical significance of research conducted in the article is to design convenient for practical using, and versatile methods to decide on the economic advisability of modernization equipment like industrial and domestic using.

Keywords: modernization, industrial equipment, methodic approaches, facilities improvement, equipment modernization advisability.

Вступ. Сучасний етап промисловості, як і більшості інших галузей національного господарського комплексу держави, зумовлює необхідність здійснення повномасштабної модернізації виробничих процесів та виробничого устаткування, як єдиної можливості забезпечити довгострокове стабільне зростання промислового виробництва відповідно до парадигми сталого розвитку.

Основою науково-технічного прогресу, за засадах якого базується сталий розвиток нашої національної економіки, є прискорений розвиток промисловості країни i, зокрема, машинобудування як провідної галузі. Машинобудівна промисловість призначена для випуску систем і комплектів машин, обладнання i приладів найвищого техніко-економічного рівня, які повинні забезпечити революційні зміни в технології та організації виробництва, підвищення продуктивності праці, зменшення матеріалоємності та енергоємності, підвищення якості продукції, Все це можна досягти шляхом оновлення виробничого апарату промислових підприємств, а саме за рахунок придбання нового сучасного устаткування або за рахунок проведення модернізації діючого, яке вже має ознаки фізичного зносу та техніко-економічного спрацювання.

У загальному вигляді під модернізацію розуміється процес цілісного оновлення суспільства, його переходу від традиційної моделі до сучасної згідно 3 новітніми вимогами й нормами [1]. Основними ознаками модернізації вважаються розширення можливостей для використання сучасних технологій у ключових галузях матеріального виробництва; розширення форм споживання; створення соціальних, політичних i культурних умов для розвитку нового сучасного виробництва. Таким чином, модернізація - процес комплексний, який передбачає трансформування не тільки економічної, але й інших сфер суспільства відповідно до обраних 
цілей i,як правило, за певними канонами. При цьому економічний аспект вважається найочевиднішим індикатором модернізації.

Питанням модернізації промислового устаткування, в тому числі й обгрунтуванні доцільності їі присвячено чимало праць вітчизняних вчених (таких, зокрема, як О. А. Гавриш, В. В. Дергачова, С. Ф. Покропивний, Г. О. Швиданенко)

Водночас недостатньо висвітленими залишаються проблеми сутності модернізації та економічного обгрунтування доцільності модернізації деяких видів промислового устаткування. Тобто віддаючи належне внеску наукових напрацювань у розвиток теорії модернізації, варто відмітити, що дослідженню процесів оцінювання доцільності модернізації промислового устаткування на сьогодні не приділено достатньої уваги. Також потребують уточнення економічна сутність самого поняття «модернізація» та доопрацювання методичних підходів (інструментарію) доцільності модернізації промислового устаткування.

Постановка завдання. Метою даної статті є грунтовне дослідження теоретичних положень та підходів щодо визначення економічної сутності модернізації промислового устаткування та розробка дієвих сучасних методичних підходів щодо обгрунтування доцільності такої модернізації.

Методологія. У процесі дослідження було використано абстрактнологістичний метод, який використовувався при узагальненні поняття «модернізація», а також методи індукції і дедукції для одержання висновків, виходячи з аналізованої теоретичної бази та розширення знань. Окрім того, в даній статті використовувалися методи порівняння і систематизації для визначення окремих ознак елементів, їх порівняння та зведення у певні групи за подібністю даній ознаці.

Результати дослідження. В сучасних умовах за недостатністю розвитку машинобудівного комплексу країни 3 метою підвищення ефективності створення нових видів устаткування і процесу відтворення основних фондів підприємств багато важить модернізація діючого виробничого устаткування. В той же час, поняття модернізації все ще трактується по різному. Це незначна, на перший погляд, обставина $є$ серйозним гальмом для розвитку суспільного виробництва. Наприклад, поширеною помилкою $\epsilon$ те, що під поняттям «модернізація» у багатьох випадках мають на увазі будь-які навіть незначні зміни у конструкції виробів як промислового так і побутового призначення, які можуть поліпшувати окремі споживчі властивості останніх. Такі незначні поліпшення у виробах можуть претендувати на раціоналізаторські пропозиції і навіть на корисні моделі або ж винаходи, але все ж не на модернізацію.

Трактування сутності поняття «модернізація» на різних етапах еволюції економічної думки надано в табл. 1.

Виконаний нами аналіз наукової літератури свідчить про те, що поняття « модернізація» є одночасно і технічним терміном, і економічною категорією. Модернізація в якості економічної категорії була i $\epsilon$ предметом вивчення багатьох вчених-дослідників і спеціалістів практиків. Тобто модернізація в широкому розумінні $\epsilon$ досить багатогранною економічною категорією за 
своєю сутністю і сучасна економічна думка трактує їі, відображаючи передові вимоги до предметів праці і знарядь виробництва.

Таблиця 1

\section{Сутність поняття «модернізація» на різних етапах еволюції економічної думки}

\begin{tabular}{|c|c|}
\hline Джерело & Трактування сутності модернізації \\
\hline $\begin{array}{l}\text { Советский } \\
\text { энциклопедический словарь. } \\
\text { - М.: Советская } \\
\text { Энциклопедия, 1986. - С. } 819\end{array}$ & 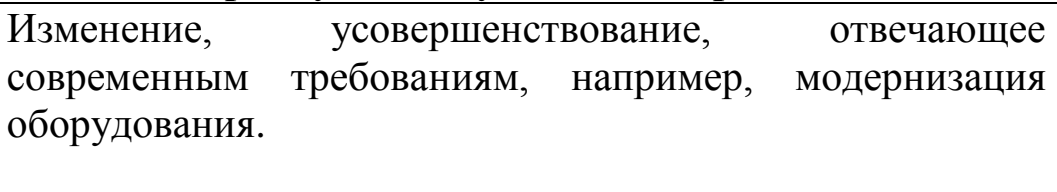 \\
\hline $\begin{array}{l}\text { С.И. Ожегов. Словарь } \\
\text { русского языка. - М.: } \\
\text { Советская энциклопедия, } \\
\text { 1968. - С. } 348 .\end{array}$ & $\begin{array}{l}\text { Модернизировать - вводя усовершенствования, сделать } \\
\text { (делать) отвечающим современным требованиям. }\end{array}$ \\
\hline $\begin{array}{l}\text { Новый политехнический } \\
\text { словарь. - М.: Большая } \\
\text { Российская энциклопедия, } \\
\text { 2000. - С. } 305 .\end{array}$ & 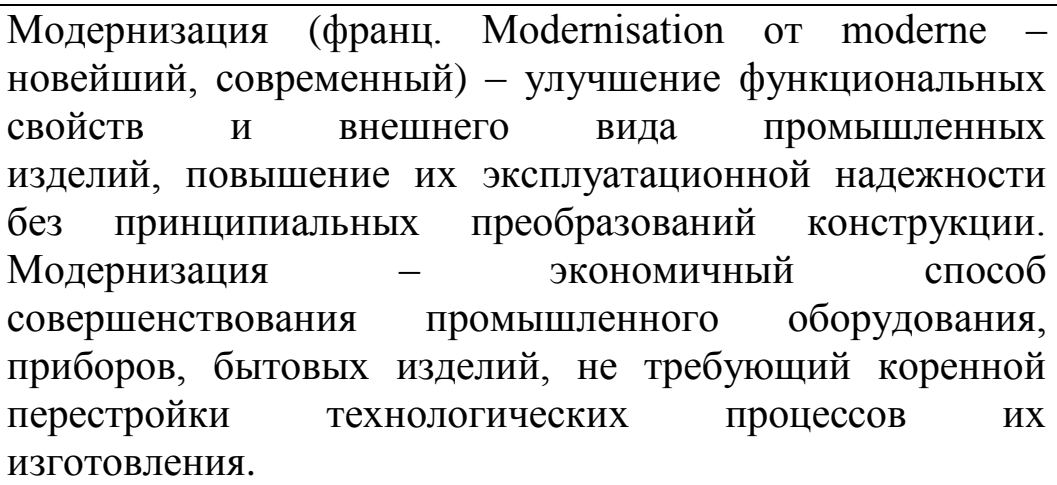 \\
\hline $\begin{array}{l}\text { Економіка підприємства: } \\
\text { Підручник / За заг. ред. С. Ф. } \\
\text { Покропивного. - Вид. 2, } \\
\text { перероб. та доп. - К.: КНЕУ, } \\
2000 . \text { - С. } 113 .\end{array}$ & $\begin{array}{l}\text { Модернізація діючого виробничого устаткування, котра } \\
\text { означає його вдосконалення і метою запобігання техніко- } \\
\text { економічного старіння та підвищення техніко- } \\
\text { експлуатаційних параметрів до рівня сучасних вимог. }\end{array}$ \\
\hline
\end{tabular}

* Систематизовано і укладено автором.

3 нашої точки зору модернізація устаткування - це, перш за все, найбільш раціональний i найбільш економічний спосіб удосконалення промислового обладнання, приладів, побутових приладів, яка не передбачає корінної перебудови технологічних процесів їх виготовлення. В той же час ми вважаємо, що модернізація устаткування означає створення на базі існуючих застарілих зразків найновіших конструкцій 3 підвищеними до сучасного рівня показниками призначення, надійності, технологічності, ергономічності, екологічності, безпеки.

Суттєвими перевагами модернізації устаткування є порівняно невеликі витрати ресурсів на іiі проведення у відносно короткі строки. Вітчизняний та зарубіжний досвід показує, що проведення модернізації, наприклад, металообробного устаткування збільшує його продуктивність на 10-12 \%, а пов’язані $з$ ним витрати ресурсів не перевищують навіть половини вартості нових видів устаткування аналогічного призначення [4, с. 15]. Економічно доцільно модернізацію промислового устаткування поєднувати 3 капітальними ремонтами останнього. 
Сутність методу визначення ефективності витрат на модернізацію така ж, як і визначення витрат на проведення капітального ремонту. Для цього можна користуватися формулою (1), поставивши в іiі чисельнику витрати на модернізацію устаткування, тобто коефіцієнт ефективності витрат на модернізацію можна розрахувати таким чином [6, с. 113]:

$$
E_{p M}=1=\frac{R_{i}+M+S_{e}}{K_{u} \cdot \alpha \cdot \beta+S_{a}},
$$

де $R_{i}$ - витрати на проведення капітального ремонту устаткування, грн.; $M-$ витрати на модернізацію, грн.; $S_{e}$ - перевищення експлуатаційних витрат щодо капітально відремонтованої або модернізованої машини над поточними витратами щодо нової машини (устаткування), грн.; $K_{н}$ - вартість придбання (ціна) та витрати для введення в експлуатацію нової машини, грн.; $S_{a}$ втрати від недоамортизації діючого устаткування, грн.; $\alpha$ і $\beta$-коефіцієнти, що враховують співвідношення, відповідно, продуктивності діючої та нової машини $(\alpha)$ та тривалості ремонтного циклу тих самих типів устаткування ( $\beta)$.

Коефіцієнти ефективності витрат, які обчислені за формулою (1) можуть набувати додатного від'ємного або нульового значення. За всіх додатних значень коефіцієнта $E_{p м}$ капітальний ремонт устаткування 3 одночасною модернізацією є економічно виправданий, за від'ємних - недоцільний, а за нульового значення коефіцієнта порівнювані варіанти треба вважати рівноцінними.

Запропонований вище метод визначення ефективності витрат на модернізацію устаткування $\epsilon$ універсальним, тобто його можна застосовувати як для промислового устаткування та пристосувань такі для побутових приладів і машин. Але цей метод має певні недоліки. Іншими словами він не враховує ряд важливих факторів, які необхідно брати до уваги при прийнятті рішення щодо модернізації конкретних типів устаткування. Зокрема, з нашої таки точки зору, доцільно, приймаючи рішення про модернізацію враховувати такі техніко-економічні показники, перелік і методи розрахунку яких наведено в табл. 2.

Таблиця 2

Техніко-економічні показники і методи їх розрахунку

\begin{tabular}{|l|l|c|c|}
\hline $\begin{array}{c}\text { № } \\
\text { 3/n }\end{array}$ & \multicolumn{1}{|c|}{$\begin{array}{c}\text { Найменування } \\
\text { показників }\end{array}$} & $\begin{array}{c}\text { Умовне } \\
\text { позна- } \\
\text { чення }\end{array}$ & Методи розрахунку показників \\
\hline 1. & $\begin{array}{l}\text { Питома енергоємність } \\
\text { устаткування }\end{array}$ & $\Pi E$ & $\Pi E=\frac{\begin{array}{l}\text { встановлена потужність } \\
\text { устаткування (кВт) }\end{array}}{\begin{array}{l}\text { продуктивність } \\
\text { устаткування }\end{array}}$ \\
\hline 2. & $\begin{array}{l}\text { Питома } \\
\text { матеріалоємність } \\
\text { устаткування }\end{array}$ & $\Pi M$ & маса устаткування \\
\hline
\end{tabular}




\begin{tabular}{|c|c|c|c|}
\hline \multirow[t]{2}{*}{3.} & \multirow{2}{*}{$\begin{array}{l}\text { Інтегральний показник } \\
\text { якості устаткування }\end{array}$} & \multirow[t]{2}{*}{$\Pi I$} & продуктивність устаткування \\
\hline & & & $\begin{array}{c}\text { витрати } \\
\text { на виготовлення } \\
\text { устаткування }\end{array} \quad \begin{array}{c}\text { витрати під час } \\
\text { експлуатації } \\
\text { устаткування }\end{array}$ \\
\hline \multirow[t]{3}{*}{4.} & \multirow{3}{*}{$\begin{array}{l}\text { Показники надійності } \\
\text { устаткування в т.ч. } \\
\text { довговічність, } \\
\text { безвідмовність, } \\
\text { ремонтопридатність }\end{array}$} & ПНД & $\begin{array}{l}\text { ПНД - устаткування зберігає свою } \\
\text { роботоздатність (календарна тривалість } \\
\text { експлуатації до певного граничного стану; }\end{array}$ \\
\hline & & $\Pi H Б$ & $\begin{array}{l}\text { ПНБ - час, протягом якого устаткування } \\
\text { зберігає свою роботоздатність до першої } \\
\text { відмови; }\end{array}$ \\
\hline & & $\Pi H P$ & $\begin{array}{l}\text { ПНР - характеризує можливість швидко } \\
\text { виявляти і усувати несправності у виробах }\end{array}$ \\
\hline 5. & $\begin{array}{l}\text { Екологічні показники } \\
\text { устаткування }\end{array}$ & $E K$ & $\begin{array}{l}E K \text { - характеризують ступінь шкідливого } \\
\text { впливу устаткування на здоров’я людини і } \\
\text { довкілля (токсичність виробів, обсяг шкідливих } \\
\text { викидів у довкілля тощо) }\end{array}$ \\
\hline 6. & $\begin{array}{l}\text { Ергономічні показники } \\
\text { устаткування }\end{array}$ & $E P$ & $\begin{array}{l}E P \text { - характеризують відповідність техніко- } \\
\text { експлуатаційних параметрів устаткування } \\
\text { антропометричним, фізіологічним та } \\
\text { психологічним вимогам працівника } \\
\text { (споживача) }\end{array}$ \\
\hline 7. & $\begin{array}{l}\text { Естетичні показники } \\
\text { устаткування }\end{array}$ & $E C$ & $\begin{array}{l}E C \text { - визначають естетичні властивості (дизайн) } \\
\text { устаткування (виразність і оригінальність } \\
\text { форми, кольорове оформлення) }\end{array}$ \\
\hline 8. & $\begin{array}{l}\text { Показники безпеки } \\
\text { устаткування }\end{array}$ & $\Pi Б$ & $\begin{array}{l}\text { ПБ - характеризують ступінь безпечності } \\
\text { устаткування для персоналу, який обслуговує } \\
\text { це устаткування }\end{array}$ \\
\hline
\end{tabular}

Показники (1-4) рекомендовано обчислювати у натуральній формі, а показники (5-8) - із застосуванням бальної оцінки.

Враховуючи, що метод визначення доцільності проведення модернізації устаткування базується на порівнянні витрат модернізованого устаткування 3 новим устаткуванням аналогічного призначення, загальновідому формулу (1) пропонуємо викласти у дещо зміненому вигляді, а саме,

$$
R_{i}+M+S_{e}=K_{\mu} \cdot a_{1} \cdot a_{2} \cdot a_{3} \cdot a_{4} \cdot a_{5} \cdot a_{6} \cdot a_{7} \cdot a_{8} \cdot a_{9} \cdot a_{10}+S_{a} .
$$

Коефіцієнти вагомості $\left(a_{1} \div a_{10}\right)$, які входять до складу формули (2), рекомендується розраховувати за методикою, яка приведена в табл. 3 . 
Таблиця 3

Коефіціснти вагомості в розрахунках доцільності модернізації устаткування

\begin{tabular}{|c|c|c|c|}
\hline $\begin{array}{l}\text { № } \\
3 / n\end{array}$ & Найменування коефіиієнта вагомості & 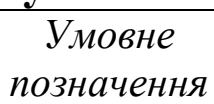 & Метод розрахунку \\
\hline 1. & Енергоємність устаткування & $a_{1}$ & $a_{1}=\frac{\Pi E_{\sigma}}{\Pi E_{\mu}}$ \\
\hline 2. & Матеріалоємність устаткування & $a_{2}$ & $a_{2}=\frac{\Pi M_{\sigma}}{\Pi M_{u}}$ \\
\hline 3. & Якість устаткування & $a_{3}$ & $a_{3}=\frac{\Pi I_{\sigma}}{\Pi I_{H}}$ \\
\hline 4. & Довговічність устаткування & $a_{4}$ & $a_{4}=\frac{\Pi H Д_{\sigma}}{\Pi H Д_{н}}$ \\
\hline 5. & Безвідмовність устаткування & $a_{5}$ & $a_{5}=\frac{\Pi H b_{\sigma}}{\Pi H b_{n}}$ \\
\hline 6. & Ремонтопридатність устаткування & $a_{6}$ & $a_{6}=\frac{\Pi H P_{\sigma}}{\Pi H P_{H}}$ \\
\hline 7. & Екологічність устаткування & $a_{7}$ & $a_{7}=\frac{E K_{\sigma}}{E K_{H}}$ \\
\hline 8. & Ергономічність устаткування & $a_{8}$ & $a_{8}=\frac{E P_{\sigma}}{E P_{H}}$ \\
\hline 9. & Естетичність устаткування & $a_{9}$ & $a_{9}=\frac{E C_{\sigma}}{E C_{H}}$ \\
\hline 10. & Безпечність устаткування & $a_{10}$ & $a_{10}=\frac{\Pi \delta_{\sigma}}{\Pi \delta_{H}}$ \\
\hline
\end{tabular}

* Індекси «б» i «н» в ознаці показників вказують на належність устаткування відповідно до базової моделі (тобто до модернізації) та нової моделі устаткування.

Для зручності в користуванні формулу (2) можна представити в такому вигляді:

$$
E_{p M}=1-\frac{R_{i}+M+S_{e}}{K_{H} \cdot a_{1} \cdot a_{2} \cdot a_{3} \cdot a_{4} \cdot a_{5} \cdot a_{6} \cdot a_{7} \cdot a_{8} \cdot a_{9} \cdot a_{10}+S_{a}} .
$$

Нескладно зробити висновки про те, що позитивні значення показника $E_{p м} \quad$ свідчать про економічну доцільність проведення модернізації устаткування у порівнянні 3 придбанням нового аналогічного зразку. Негативне значення показника $E_{p м}$ вказує на економічну доцільність придбання нового устаткування тому, що сукупні витрати на капітальний ремонт устаткування та одночасну модернізацію перевищують витрати на придбання нового устаткування.

У процесі техніко-економічного аналізу при здійсненні модернізації устаткування крім вище означеного і запропонованого нами показника ефективності витрат (3) необхідно додатково обчислювати інші показники, які дозволяють прийняти правильне рішення щодо модернізації. До цих 
показників можна віднести наступні: термін окупності додаткових капітальних вкладень (витрат на модернізацію); коефіцієнт ефективності додаткових капітальних вкладень; річний економічний ефект від модернізації тощо.

Висновки. У процесі дослідження, яке було проведено в рамках даної статті, дістав подальшого розвитку понятійно-категоріальний апарат у частині уточнення понять «модернізація» та «модернізація промислового устаткування». На відміну від наявних визначень запропоновано трактувати модернізацію як комплекс робіт по створенню виробів 3 підвищеними функціональними властивостями, які підвищують, в першу чергу, їх експлуатаційні показники та показники надійності без принципових змін їх конструкцій та принципу дій. Таким чином, модернізація промислового устаткування передбачає комплекс робіт по вдосконаленню діючого устаткування 3 метою досягнення цим устаткуванням показників та характеристик найсучасніших у світі зразків-аналогів.

Практичне значення дослідження полягає в розробці зручної для практичного використання універсальної методики щодо прийняття рішення про економічну доцільність здійснення модернізації устаткування як промислового, так і побутового призначення. На відміну від існуючих методик запропонована нами методика вміщує більшу кількість технікоекономічних показників, які дозволяють прийняти з більшою вірогідністю економічно обгрунтоване рішення щодо модернізації.

В кожній галузі суспільного виробництва, а також у побуті існує значна кількість знарядь праці (устаткування), які 3 плином часу можуть продовжити свій життєвий цикл за рахунок модернізації. Але ці види устаткування можуть значно відрізнятися один від одного.

Тому перспективами подальших наукових розробок в даному напрямку $\epsilon$ дослідження стосовно особливостей, обгрунтування економічної доцільності проведення модернізації вже більш конкретних видів промислового устаткування в машинобудуванні, хімічній, металургійній, харчовій та інших галузях промисловості та в побуті.

\section{Література:}

1. Большая советская энциклопедия. - М.: Советская энциклопедия, 1974. Изд. 3. T. 16. - C. 402.

2. Бокарев Ю.П. Теории модернизации и экономическое развитие // Вестник РГГУ. Серия «Экономика». - 2009. - № 3. - С. 14-25.

Режим

3. Смирнов О. Модернизация без инноваций - тупик [Электронный ресурс]. html. доступа:

http://www.ng.ru/politics/2010-03-24/1_modernize.

4. Экономическое обоснование инженерных решений / С.Ф. Покропивный. - К.: Техника, 1985. - $206 \mathrm{c.}$

5. Основы технико-экономического анализа инженерных решений / А.Э. Розенплентер, В.С. Сычов, С.П. Чернышов, И.С. Шур. - К.: Вища школа, 1989. - 124 с.

6. Економіка підприємства: Підручник / За заг. ред. С. Ф. Покропивного. - Вид. 2-ге, перероб. та доп. - К.: КНЕУ, 2000. - 528 с. 